PAPER

\title{
Latitudinal variation in the prevalence of multiple sclerosis in Ireland, an effect of genetic diversity
}

\author{
C McGuigan, A McCarthy, C Quigley, L Bannan, S A Hawkins, M Hutchinson
}

J Neurol Neurosurg Psychiatry 2004;75:572-576. doi: 10.1136/jnnp.2003.012666

See end of article for authors' affiliations ....................

Correspondence to: Dr C McGuigan, Department of Neurology, St Vincent's University Hospital, Elm Park, Dublin 4, Republic of Ireland; cmcguigan@ doctors.org.uk

Received 17 February 2003 In revised form

20 August 2003

Accepted 20 August 2003

\begin{abstract}
Background: Northern Ireland has a high and rising prevalence rate of multiple sclerosis (MS). The most recent survey in 1996 found a rate of 168.7/100 000. Recorded prevalence rates for the south of Ireland, including County Wexford, have been markedly lower and seemed to suggest the existence of a prevalence gradient within the island.

Objectives: To compare the prevalence of multiple sclerosis in Co. Wexford in the south east of Ireland and Co. Donegal in the north west, and to establish whether a variation in prevalence of MS exists within Ireland.

Methods: Patients were referred from multiple sources. Review of clinical case records and/or patient examination confirmed the diagnosis.

Results: In Co. Wexford, 126 patients were found to have clinically definite or probable multiple sclerosis with a prevalence rate of $120.7 / 100000$ (95\% confidence intervals (Cl) 100.6 to 143.8), which is similar to other areas of similar latitude within the British Isles. In Co. Donegal, 240 people had clinically definite or probable MS with a prevalence rate of $184.6 / 100000(95 \% \mathrm{Cl} 162.0$ to 209.5). The difference in prevalence rates is statistically significant $(Z=3.94, p=<0.001)$.

Conclusion: There is a latitudinal variation in the prevalence rate of $M S$ between the north and the south of Ireland. The increased prevalence of MS seen in Co. Wexford is likely to represent better case ascertainment and improved diagnostic accuracy rather than an actual increase in prevalence. The north/ south variation in prevalence may represent a variation in the genetic predisposition to MS between the background populations of the two counties.
\end{abstract}

1 reland has been recognised as a high risk area for multiple sclerosis (MS) since the pioneering work of Allison and Millar in the 1950s. ${ }^{1}$ Their initial study, conducted on the entire population of Northern Ireland, identified a prevalence rate for possible or probable MS of 51/100 000. Further studies in the same population showed high and rising prevalence rates..$^{2-4}$ The most recent study, conducted in the north east of the island reported a prevalence rate for clinically definite and probable MS (Poser criteria) ${ }^{5}$ of 168.2/ $100000,{ }^{3}$ one of the highest prevalence figures within western Europe.

In contrast, the Republic of Ireland has been less extensively studied. Brady ascertained the prevalence rate of MS in the country as a whole as 77/100 000 in $1977 .{ }^{6}$ In a population of 3.5 million, case ascertainment was likely to have been sub-optimal. County Wexford in the south east of Ireland has been studied on two occasions; in 1971, Brady and Dean reported a prevalence rate of 54.5/100 $000^{6}$ and in 1984 the prevalence rate was estimated to be $48.4 / 100000 .^{7}$

The north/south differences in prevalence rates within the island of Ireland have suggested a gradient, but in the absence of a modern study in the Republic of Ireland, this was uncertain.

Variations in the prevalence of MS based on latitude have previously been reported within other regions of the British Isles $^{8}$ and worldwide. ${ }^{9}{ }^{10}$ In recent years some doubt has been cast on the validity of these observations within England and Wales, ${ }^{11}$ although an increase in prevalence from England up to Scotland seems to be reinforced with further scrutiny of the methods, including capture-recapture adjustment of prevalence rates. ${ }^{12}$ This step in prevalence between England and Scotland remains unexplained.

In order to address the question of the low prevalence rate of MS in the south east of Ireland in relation to the north of the island, this study of Co. Wexford and Co. Donegal was devised.

\section{METHODS}

\section{Study areas}

Co. Wexford is a maritime and farming county in the south east of Ireland lying between $52^{\circ} 20^{\prime}$ and $52^{\circ} 44^{\prime}$ latitude north with a land area of $1454 \mathrm{~km}^{2}$ and a population of $104372 . .^{13}$ Co. Donegal is located on the Atlantic coast in the north west of Ireland. It lies between $54^{\circ} 80^{\prime}$ and $55^{\circ} 43^{\prime}$ latitude north (fig l), and has a land area of $1876 \mathrm{~km}^{2}$ and a population of 129 994. ${ }^{13}$ Both counties have a general teaching hospital located in the main county town, and neurological services are provided by the teaching hospitals in Dublin.

\section{Case ascertainment}

Ethical approval for the study was obtained from the ethics committee of St. Vincent's University Hospital, Dublin.

Patients with the diagnosis of multiple sclerosis were ascertained from the following sources: general practitioners in Co. Wexford and Co. Donegal, consultant neurologists throughout Ireland, and county physicians in Wexford and Donegal; hospital coding lists, the local and national MS societies, respite care facilities, and interferon prescription lists.

\section{Definition of prevalence}

Individuals were considered prevalent if they had clinically definite or probable MS as defined by the Poser diagnostic

Abbreviations: MS, multiple sclerosis 


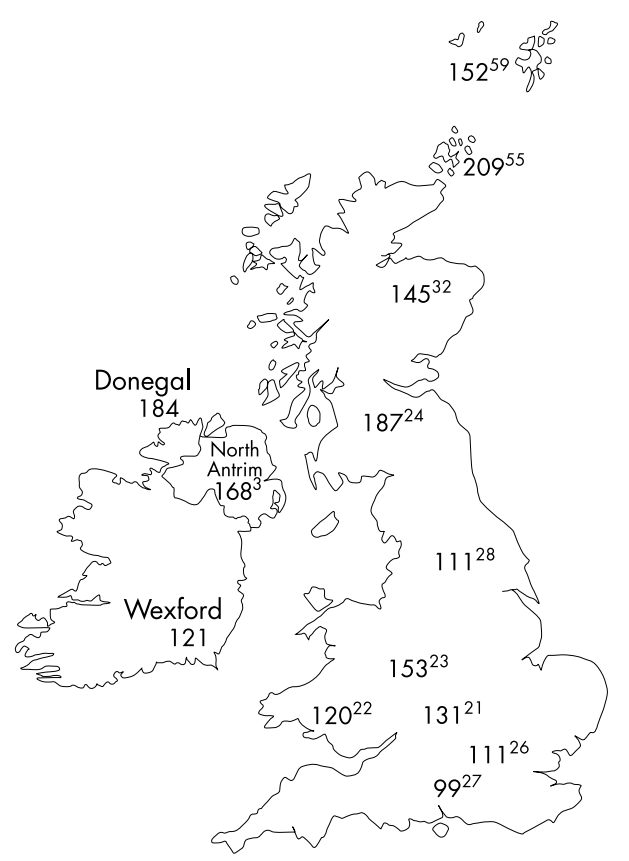

Figure 1 Map of the British Isles indicating the location of the study areas and the prevalence rates. The prevalence rate is the figure stated per 100000 population, and the superscript figure is the study reference.

criteria $^{5}$ and were resident within the county borders on 1 January 2001.

\section{Patient assessment methods}

All prevalent cases were invited to interview in Wexford General Hospital or Letterkenny General Hospital, Donegal. If this was not possible, a home visit was arranged. At interview, all cases had their demographic information recorded and historical notes assessed. The diagnosis of MS was confirmed by review of clinical case records and neurological examination. The Kurtzke Expanded Disability Status Scale ${ }^{14}$ and the Multiple Sclerosis Functional Composite ${ }^{15}$ scores were recorded.

If a general practitioner felt it was inappropriate to supply a patient's name or contact details he or she was requested to provide sufficient information to ensure the case had not already been ascertained and to confirm the diagnosis.

\section{Statistical methods}

Ninety-five percent confidence intervals (CI) were calculated using a standard formula. ${ }^{11}$ The prevalence rates for Co.
Wexford and Co. Donegal were compared using a $\mathrm{Z}$ value, where $\mathrm{Z}$ is a standard normal deviate. The correlation between Wexford, Donegal, and other studies within the British Isles compared with latitude was assessed using Spearman's rank coefficient ( $r$ ). A two source capturerecapture method ${ }^{16}$ was used as a measure of the likely number of missed cases. Survey completeness or "coverage" was expressed as a percentage of observed over expected cases. ${ }^{17}$ Standardised prevalence rates were calculated using the population of Northern Ireland from the 1996 study by McDonnell and Hawkins to allow direct comparison. ${ }^{3}$

\section{RESULTS}

\section{County Wexford}

The total number of cases ascertained from all sources was 161; 96 of these were referred from multiple sources. The number referred from each source included 46 from general practitioners, 51 from consultant neurologists, 94 from general physicians and hospital coding lists, and 33 from the MS society. Respite facilities and interferon prescription lists accounted for a further 27 referrals. Neither of these two latter sources contributed any unique cases. Twenty two patients were excluded from the study because the diagnosis was incorrect (7), or the patient was not resident within the study area (8) or was deceased prior to our defined prevalence day (7). Of the remaining patients 126 had clinically definite or probable MS, resulting in a prevalence rate for MS in Co. Wexford of 120.7/100 000 (95\% CI 100.6 to 143.8). Age/sex specific prevalence rates for the county are displayed in table 1 . The highest prevalence rates for men and women were in the $45-54$ year age range. A further 13 cases had clinically possible disease. Applying two source capturerecapture adjustments to our data indicated that the likelihood estimate of missed cases for each source was between 4 (consultant physicians, neurologists and hospital coding lists) and 12 (general practitioners) missed cases. The range of adjusted prevalence rates when the estimated number of missed cases are included is 124.6-132.2/100 000. The estimated coverage of the study is $91.3-96.9 \%$. (table 2) Disease characteristics for the prevalent population are given in table 3.

\section{County Donegal}

The total number of cases ascertained from all sources was 280; 128 were referred from multiple sources. The number referred from each source included 96 from general practitioners, 76 from consultant neurologists, general physicians and hospital coding lists, and 174 from the MS society. Respite facilities and interferon prescription lists accounted for a further 30 referrals; once again, neither of these two sources contributed any unique cases. Thirty one patients

\begin{tabular}{|c|c|c|c|c|c|c|c|c|c|c|c|c|}
\hline \multirow{3}{*}{$\begin{array}{l}\text { Age } \\
\text { range } \\
\text { (years) }\end{array}$} & \multicolumn{6}{|c|}{ Co. Wexford } & \multicolumn{6}{|c|}{ Co. Donegal } \\
\hline & \multicolumn{2}{|c|}{ Women } & \multicolumn{2}{|l|}{ Men } & \multicolumn{2}{|c|}{ Total } & \multicolumn{2}{|c|}{ Women } & \multicolumn{2}{|l|}{ Men } & \multicolumn{2}{|c|}{ Total } \\
\hline & No. & Prev. & No. & Prev. & No. & Prev. & No. & Prev. & No. & Prev. & No. & Prev. \\
\hline $0-14$ & 0 & 0 & 0 & 0 & 0 & 0 & 0 & 0 & 0 & 0 & 0 & 0 \\
\hline $15-24$ & 4 & 49 & 1 & 11 & 5 & 29.2 & 4 & 36 & 1 & 9 & 5 & 22.9 \\
\hline $25-34$ & 8 & 113 & 5 & 69 & 13 & 90.8 & 23 & 254 & 7 & 78 & 30 & 167.0 \\
\hline $35-44$ & 22 & 318 & 9 & 128 & 31 & 222.3 & 53 & 715 & 12 & 164 & 65 & 442.3 \\
\hline $45-54$ & 24 & 407 & 14 & 226 & 38 & 305.6 & 44 & 647 & 15 & 218 & 59 & 426.1 \\
\hline $55-64$ & 16 & 364 & 10 & 221 & 26 & 291.1 & 36 & 630 & 9 & 160 & 45 & 397.2 \\
\hline 65-74 & 5 & 135 & 6 & 178 & 11 & 155.0 & 18 & 377 & 8 & 170 & 26 & 274.9 \\
\hline $75+$ & 1 & 33 & 1 & 53 & 2 & 40.1 & 7 & 179 & 3 & 78 & 10 & 129.2 \\
\hline Total & 80 & 154 & 46 & 88 & 126 & 120.7 & 185 & 282 & 55 & 85 & 240 & 184.6 \\
\hline
\end{tabular}


Table 2 Two source capture-recapture adjustments applied to the main sources of case ascertainment (general practioners, hospital coding lists/physicians/neurologists, and the MS society) by county.

\begin{tabular}{|c|c|c|c|c|c|c|}
\hline & \multicolumn{3}{|c|}{ Co. Wexford } & \multicolumn{3}{|c|}{ Co. Donegal } \\
\hline & GPs & $\begin{array}{l}\text { Hospital coding } \\
\text { lists/physicians/ } \\
\text { neurologists }\end{array}$ & $\begin{array}{l}\text { MS } \\
\text { society }\end{array}$ & GPs & $\begin{array}{l}\text { Hospital coding } \\
\text { lists/physicians/ } \\
\text { neurologists }\end{array}$ & $\begin{array}{l}\text { MS } \\
\text { society }\end{array}$ \\
\hline Total in source $(a+b)$ & 46 & 108 & 33 & 96 & 76 & 174 \\
\hline Unique to source (b) & 6 & 20 & 3 & 8 & 11 & 38 \\
\hline Common to all sources (a) & 40 & 88 & 30 & 88 & 65 & 136 \\
\hline Not in source (c) & 80 & 18 & 93 & 144 & 164 & 66 \\
\hline Unobserved (bc/a) & 12 & 4 & 9 & 13 & 27 & 18 \\
\hline $\begin{array}{l}\text { Estimated size of population } \\
a+b+c+(b c / a)\end{array}$ & 138 & 130 & 135 & 253 & 267 & 258 \\
\hline Coverage $(\%)$ & 91.3 & 96.9 & 93.3 & 94.9 & 89.9 & 93.0 \\
\hline $\begin{array}{l}\text { Ascertainment adjusted } \\
\text { prevalence (per } 100000 \text { ) }\end{array}$ & 132.2 & 124.6 & 129.3 & 194.6 & 205.4 & 198.5 \\
\hline
\end{tabular}

were excluded from the study because the diagnosis was incorrect (11), or the patient was not resident within the study area (5) or was deceased prior to our defined prevalence day (15). Of the remaining 249 cases, 240 had clinically definite or probable disease, resulting in a prevalence rate for MS in Co. Donegal of 184.6/100 000 (95\% CI 162.0 to 209.5). Age/sex specific prevalence rates are given in table 1. A further nine cases had clinically possible MS, resulting in a crude prevalence rate of 191.5/100 000 (95\% CI 168.5 to 216.9). Applying two source capture-recapture adjustments to our data indicated that the likely number of missed cases was 13 (general practitioners) to 27 (consultant physicians, neurologists and hospital coding lists). Including the number of missed cases adjusted the prevalence rate to Donegal from 194.6-205.4/100 000. The estimated coverage of the study was $89.9-94.9 \%$ (table 2). Disease characteristics for the prevalent population are shown in table 3.

\section{Comparison between the two counties}

The prevalence rate for Co. Wexford was significantly lower than that for Co. Donegal $(Z=3.94, p=<0.001)$. The difference in the prevalence rates is $63.9 / 100000(95 \% \mathrm{CI}$ 49.3 to 82.7 ).

Age standardisation of the prevalence rate for both counties against the population from the 1996 study in the north east of Ireland ${ }^{3}$ adjusted the prevalence rates to 121.2/

Table 3 Disease characteristics for the prevalent population for both Co. Wexford and Co. Donegal

\begin{tabular}{|c|c|c|}
\hline Disease characteristic & Co. Wexford & Co. Donegal \\
\hline Average age, years (range) & 47.2 (19-73) & $48.9(24-78)$ \\
\hline $\begin{array}{l}\text { Mean age at onset, years } \\
\text { (range) }\end{array}$ & 33.4 (14-57) & $32.8(14-56)$ \\
\hline Average duration of $M S$, years & 13.4 & 16.1 \\
\hline Female : male ratio & $1.7: 1$ & $3.4: 1$ \\
\hline Mean annualized incidence & 4.47 & 5.12 \\
\hline rate/ $100000 /$ year $(95 \% \mathrm{Cl})$ & (0.27 to 8.67$)$ & (1.6 to 11.7$)$ \\
\hline \multicolumn{3}{|l|}{ Clinical course (\%) } \\
\hline Primary progressive & 12.5 & 10.7 \\
\hline Relapsing/remitting & 48.9 & 51.1 \\
\hline Secondary progressive & 38.6 & 38.2 \\
\hline $\begin{array}{l}\text { Mean Kurtzke EDSS score } \\
\text { (range) }\end{array}$ & $4.36(0-9.5)$ & $4.78(0-0.5)$ \\
\hline Mean MSFC - Z score* (range) & $\begin{array}{l}-1.28 \\
(-6.55-0.77)\end{array}$ & $\begin{array}{l}-1.28 \\
(-6.55-0.77)\end{array}$ \\
\hline \multicolumn{3}{|c|}{$\begin{array}{l}{ }^{*} \text { Calculated using the task force database control. }{ }^{15} \\
\text { EDSS, Expanded Disability Status Scale; MSFC, Multiple Sclerosis } \\
\text { Functional Composite. }\end{array}$} \\
\hline
\end{tabular}

100000 for Co. Wexford and 194.6/100 000 for Co. Donegal, further strengthening the north/south gradient.

\section{DISCUSSION}

This study confirms the presence of a prevalence difference for MS between the north west and south east of Ireland. The incidence rates for the two counties studied are surprisingly similar, given the large variation in prevalence rates. This study is underpowered to perform a direct comparison of incidence rates. Difficulties in the accuracy of recording onset of first symptom, especially when only patient recall was available, may explain the lower than expected incidence rate for Co. Donegal.

The two source capture-recapture methods indicate excellent coverage (90\%-94\%) of the populations in both counties. The estimated number of missed cases compares favourably to many recent British studies in which the likely number of missed cases have ranged from 0 to 125 and percentage coverage varied from $78.2 \%$ to $99.6 \% .^{12}$ In the $1996^{3}$ Northern Ireland study, the likely number of missed cases was 18

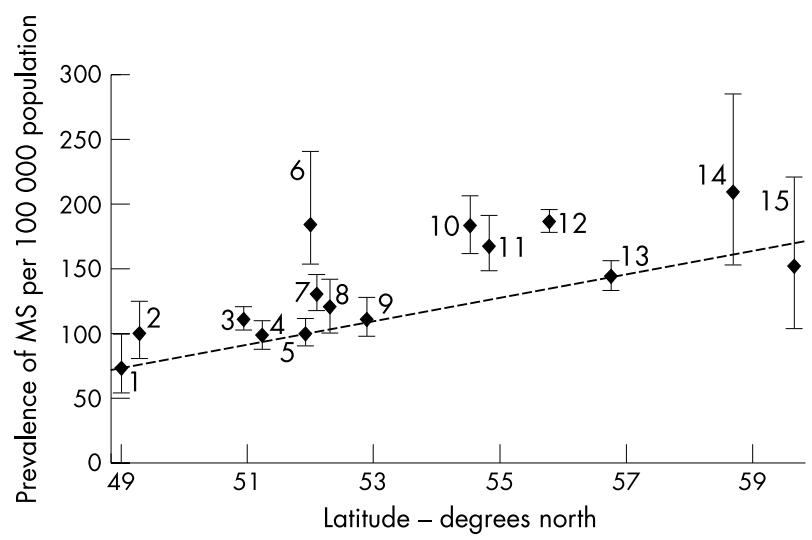

Figure 2 Graph of MS prevalence rates expressed as means $195 \%$ confidence limits) against latitude for 14 studies in the British Isles. The dashed line represents the correlation between latitude and prevalence of MS, correlation coefficient $(r)=0.65$. The numbers beside each data point indicate the following studies: (1) Guernsey 1991, ${ }^{31}(2)$ Jersey

$1991,{ }^{31}$ (3) Sussex 1991, ${ }^{26}$ (4) Southampton 1987, ${ }^{27}$ (5) south east Wales 1988, ${ }^{22}$ (6) Suffolk 1988*, 23 (7) Cambridge 1993, ${ }^{21}$ (8) Wexford 2001, (9) Rochdale 1986, ${ }^{28}$ (10) Donegal 2001, (11) N) Ireland 1996, ${ }^{3}$ (12) Lothian 1995, ${ }^{24}$ (13) Aberdeen 1980*,32 (14) Orkneys 1983*, (15) Shetland 1974*. ${ }^{*}$ Poser criteria ${ }^{5}$ of probable/definite MS used for all studies unless marked with an asterisk $\left({ }^{*}\right)$ in which case the Allison and Millar' criteria were applied. (Adapted from Robertson and Compston. "') 
(coverage 94\%) resulting in an adjusted prevalence rate of $180.1 / 100000 .^{18}$

The prevalence rate from Co. Wexford was similar to rates from areas of similar latitude within the British Isles (fig 2). In 1993, a study in the Cambridge district of East Anglia, the first such population based study in the south east of England, found a prevalence rate of 130/100 000 ${ }^{19}$ (updated in 1996 to $152 / 100000$ ), ${ }^{20}$ and a similar study in north Cambridgeshire reported a prevalence rate of MS of 119/ $100000 .^{21}$ South east Wales had a prevalence rate for MS of $120 / 100000$ in 1990..$^{22}$ A study conducted in Suffolk in 1988 produced the highest figure for the prevalence of MS in England of 153/100 000 clinically probable or definite cases of MS. ${ }^{23}$ However, this study was based on general practitioner notes only with no confirmation of the diagnosis by a neurologist. Additionally, the population size was small (31 379) and the under 35 age group was over-represented. Thus, the reported prevalence may not reliably reflect the actual prevalence rate for the Suffolk region.

The prevalence rate in Donegal is strikingly similar to that of north Co. Antrim from the 1996 study by McDonnell et al. ${ }^{3}$ It is also comparable to areas of similar latitude in the British Isles such as Lothian. ${ }^{24}$

A plot of prevalence rates of MS within the British Isles, including Wexford and Donegal, against latitude shows a moderate correlation, $\mathrm{r}=0.65$, indicating the presence of a latitudinal variation in the prevalence of MS for the British Isles (fig 2).

Wexford has been surveyed on two previous occasions. ${ }^{67}$ Our prevalence figure is much higher than either of the previously reported figures, with no overlapping of the confidence intervals. The most recent study in 1984 by Hutchinson employed the diagnostic criteria of McDonald and Halliday, ${ }^{25}$ making direct comparison with the current study difficult. In that study, all patients were also individually examined, but $40 \%$ were deemed as having benign disease. A bias against the more severely disabled may have accounted for the lower prevalence rate. It is our opinion that the increase in prevalence rates is likely to represent better case ascertainment in the current study. Prolonged patient survival, improved diagnostic accuracy, and earlier diagnosis with the widespread use of MRI will also have contributed to the higher prevalence rate.

The revised prevalence rate for Co. Wexford is significantly lower than the rate from the 1996 survey of northeast Ireland $^{3}$ and the study performed simultaneously on Co. Donegal, despite employing similar methods of case ascertainment. Thus, the evidence is that there is a latitudinal gradient within Ireland. The existence of a latitudinal gradient within England has been challenged by the prevalence rates published from several well conducted surveys over the past 20 years. ${ }^{19-21} 26-28$ Closer analysis of methodology, diagnostic criteria used, and the inclusion of possible missed cases have all tended to bring most prevalence rates within England and Wales to a similar level. ${ }^{11} 29$ However, the increased prevalence of MS in Scotland compared with England and Wales remains. ${ }^{12}$ This is likely to represent a differing rate of MS susceptibility gene prevalence, in particular HLA DRI5 (formerly HLA DR2) in the background populations. HLA DR15 is known to be more prevalent in the Scottish population compared with the south of England. ${ }^{8}$

The population in the north of Ireland has close historical and cultural links with the Scots, both deriving from Gaelic ancestry, whereas that of Wexford and the south east of Ireland has a strong Norman and English influence. The postulated background genetic north/south differences probably relate to population movements such as the 17th century settlement of Ulster by people from the Scottish lowlands and the 13th century Norman invasion of the south east of
Ireland, and they also correspond to well recognised trade and migration routes between Ireland and mainland Britain. A crude test of this hypothesis is to measure the prevalence of surnames beginning with "Mc" or "Mac" as surrogate markers of northern European (Scots/Nordic) ancestry, a method previously employed in other studies. ${ }^{1024}$ In the Co. Wexford telephone directory there are 670/100 000 such surnames, whereas in Co. Donegal in the northwest of Ireland there are 6174/100 000. We hypothesise therefore that the variation in the prevalence of MS within the island of Ireland is due to differences in the prevalence of MS susceptibility genes in the background populations of the two regions rather than a true latitudinal/environmental factor, a theory supported by the reduction in prevalence rate differences at varying latitudes with the application of age standardisation to previously reported studies. ${ }^{30}$ A study of the HLA status of the background populations in both Co. Wexford and Co. Donegal is currently in progress to test this hypothesis.

\section{ACKNOWLEDGEMENTS}

This study was supported by a Serono Fellowship from the Irish Brain Research Foundation. The authors gratefully acknowledge the contribution of Drs G Dean, G McDonnell, and R Forbes for their advice in planning this study. We thank the general practitioners, consultant physicians and neurologists for their support and the patients with MS who agreed to participate in this study.

\section{Authors' affiliations}

C McGuigan, A McCarthy, M Hutchinson, St Vincent's University Hospital, Elm Park, Dublin 4, Republic of Ireland

C Quigley, Wexford General Hospital, Wexford, Republic of Ireland

S A Hawkins, The Royal Victoria Hospital, Grosvenor Road, Belfast BT12 6BA, UK

L Bannan, Letterkenny General Hospital, Letterkenny, Republic of Ireland Competing interests: none declared

\section{REFERENCES}

1 Allison RS, Millar JH. Prevalence of disseminated sclerosis in Northern Ireland. Ulster Med J 1954;23:1-27.

2 Hawkins SA, Kee F. Updated epidemiological studies of multiple sclerosis in Northern Ireland. J Neurol 1988;235(Suppl 1):S86 (Abstract).

3 McDonnell GV, Hawkins SA. An epidemiologic study of multiple sclerosis in Northern Ireland. Neurology 1998;50:423-8.

4 Millar JHD. Multiple sclerosis in Northern Ireland. In: Clifford Rose F, ed. Clinical epidemiology. Tunbridge Wells: Pitman Medical, 1980:222-7.

5 Poser CM, Paty DW, Scheinberg L, et al. New diagnostic criteria for multiple sclerosis: guidelines for research protocols. Ann Neurol 1983;13:227-31.

6 Brady R, Dean G, Secerbegovic S, et al. Multiple sclerosis in the Republic of Ireland. Ir Med J 1977:70:500-6.

7 Hutchinson M. Disability due to multiple sclerosis: a community-based study on an Irish county. Ir Med J 1986;79:48-50.

8 Swingler RJ, Compston D. The distribution of multiple sclerosis in the United Kingdom. J Neurol Neurosurg Psychiatry 1986;49:1115-24.

9 Hammond SR, McLeod JG, Millingen KS, et al. The epidemiology of multiple sclerosis in three Australian cities: Perth, Newcastle and Hobart. Brain 1988; 111:1-25.

10 Skegg DC, Corwin PA, Craven RS, et al. Occurrence of multiple sclerosis in the north and south of New Zealand. I Neurol Neurosurg Psychiatry 1987;50:134-9.

11 Robertson N, Compston A. Surveying multiple sclerosis in the United Kingdom. J Neurol Neurosurg Psychiatry 1995;58:2-6.

12 Forbes RB, Swingler RJ. Estimating the prevalence of multiple sclerosis in the United Kingdom by using capture-recapture methodology. Am J Epidemiol 1999; 149:1016-24.

13 Central Statistics Office. 1996 Mid-term Census. Dublin: Central Statistics Office of Ireland, 1996.

14 Kurtzke JF. Rating neurologic impairment in multiple sclerosis: an expanded disability status scale (EDSS). Neurology 1983;33:1444-52.

15 Cutter GR, Baier ML, Rudick RA, et al. Development of a multiple sclerosis functional composite as a clinical trial outcome measure. Brain $1999 ; 122: 871-82$.

16 Wittes JT, Colton T, Sidel WW. Capture-recapture methods for assessing the completeness of case ascertainment when using multiple information sources. J Chronic Dis 1974;27:25-36. 
17 Hook EB, Regal RR. The value of capture-recapture methods even for apparent exhaustive surveys. The need for adjustment for source of ascertainment intersection in attempted complete prevalence studies. Am J Epidemiol 1992; 135:1060-7.

18 Forbes RB, Swingler RJ. An epidemiologic study of multiple sclerosis in Northern Ireland. Neurology 1999;52:215-16.

19 Mumford CJ, Fraser MB, Wood NW, et al. Multiple sclerosis in the Cambridge health district of east Anglia. J Neurol Neurosurg Psychiatry 1992;55:877-82.

20 Robertson N, Deans J, Fraser $M$, et al. Multiple sclerosis in south Cambridgeshire: incidence and prevalence based on a district register. $J$ Epidemiol Community Health 1996;50:274-9.

21 Robertson N, Deans J, Fraser M, et al. Multiple sclerosis in the north Cambridgeshire districts of East Anglia. J Neurol Neurosurg Psychiatry 1995:59:71-6.

22 Hennessy A, Swingler RJ, Compston DA. The incidence and mortality of multiple sclerosis in south east Wales. I Neurol Neurosurg Psychiatry 1989;52:1085-9.

23 Lockyer MJ. Prevalence of multiple sclerosis in five rural Suffolk practices. BMJ 1991;303:347-8.

24 Rothwell PM, Charlton D. High incidence and prevalence of multiple sclerosis in south east Scotland: evidence of a genetic predisposition. J Neurol Neurosurg Psychiatry 1998;64:730-5.

25 McDonald WI, Halliday AM. Diagnosis and classification of multiple sclerosis. Br Med Bull 1977;33:4-9.
26 Rice-Oxley M, Williams ES, Rees JE. A prevalence survey of multiple sclerosis in Sussex. J Neurol Neurosurg Psychiatry 1995;58:27-30.

27 Roberts MH, Martin JP, McLellan DL, et al. The prevalence of multiple sclerosis in the Southampton and South West Hampshire Health Authority. J Neurol Neurosurg Psychiatry 1991;54:55-9.

28 Shepherd DI, Summers A. Prevalence of multiple sclerosis in Rochdale. J Neurol Neurosurg Psychiatry 1996;61:415-7.

29 Forbes RB, Wilson SV, Swingler RJ. The prevalence of multiple sclerosis in Tayside, Scotland: do latitudinal gradients really exist? J Neurol 1999;246:1033-40.

30 Zivadinov R, lona L, Monti-Bragadin L, et al. The use of standardized incidence and prevalence rates in epidemiological studies on multiple sclerosis. A meta-analysis study. Neuroepidemiology 2003;22:65-74.

31 Sharpe G, Price SE, Last A, et al. Multiple sclerosis in island populations: prevalence in the Bailiwicks of Guernsey and Jersey. J Neurol Neurosurg Psychiatry 1995;58:22-6.

32 Shepherd DI, Downie AW. A further prevalence study of multiple sclerosis in north-east Scotland. J Neurol Neurosurg Psychiatry 1980:43:310-15.

33 Cook SD, Cromarty Jl, Tapp W, et al. Declining incidence of multiple sclerosis in the Orkney Islands. Neurology 1985;35:545-51.

34 Cook SD, MacDonald J, Tapp W, et al. Multiple sclerosis in the Shetland Islands: an update. Acta NeurolScand 1988;77:148-51. 